\title{
A Comparative Study of Reproduction and Development in the Polychaete Family Terebellidae
}

\author{
DAMHNAIT MCHUGH* \\ Department of Biology and Institute of Marine Sciences, University of California, \\ Santa Cruz, California 95064
}

\begin{abstract}
The reproduction and development of four species of terebellid polychaetes from the west coast of North America were studied and compared with several other terebellid species to reveal the covariation of life history traits in the group, and assess any limitations on terebellid life history evolution that may be imposed by ancestry or body design. The four species in the present study span the range of reproductive and developmental modes known for the family Terebellidae. Eupolymnia crescentis and Neoamphitrite robusta are both free spawners that reproduce during discrete 3-month breeding periods. In $E$. crescentis, oogenesis takes from 5 to 8 months and spawning occurs from July to September, maximum oocyte diameter is $210 \mu \mathrm{m}$, and fecundity reaches $\sim 128,500$ during a single breeding period. The E. crescentis larva develops near the bottom for about 7 days before settling as a five-setiger juvenile. Neoamphitrite robusta reproduces from April to July after a 12month oogenic cycle; oocytes in this species measure up to $180 \mu \mathrm{m}$, and fecundity reaches $\sim 830,000$. The two brooders in the study, Ramex californiensis and Thelepus crispus, brood their larvae in the maternal tube. T. crispus reproduces continuously for at least 6 months, and has up to 51,500 larvae in a single brood. The oocytes in this spccics $(400 \mu \mathrm{m})$ give rise to larvac that are brooded to the one-setiger stage and then emerge to undergo a oneday planktonic period before the larvae settle and become juveniles at eight setigers. Ramex californiensis reproduces continuously year round; larvae are brooded in cocoons that are laid sequentially in the tube, with up to 44 larvae in a single cocoon. Development from the $410 \mu \mathrm{m}$ oocytes
\end{abstract}

Received 18 December 1992; accepted 14 July 1993.

* Present address: Department of Invertebrate Zoology, NHB-163, National Museum of Natural History, Smithsonian Institution, Washington, DC 20560. is direct, and juveniles have 11 setigers. Unlike $E$. crescentis and $N$. robusta, in which oogenesis is synchronized within individuals to produce a peak of large oocytes during the discrete spawning period, $R$. californiensis and $T$. crispus females have a wide range of oocyte sizes throughout the year.

Correlation analysis and analysis of variance of reproductive and developmental traits of these and several other terebellid species revealed some expected trends. For example, egg size varies according to the mode of reproduction (free spawning, extratubular brooding, or intratubular brooding), and is also correlated with juvenile size. However, egg size does not predict fecundity in terebellids when body size is held constant, and brooding is not restricted to small-bodied species. Indeed, the largest and smallest species in the study brood their larvae intratubularly, suggesting that allometric constraints may not be important in determining mode of reproduction in these polychaetes. 'The Terebellidae is a diverse family found in all marine habitats, yet all known terebellid larvae are non-feeding; this contrasts with the occurrence of both planktotrophy and lecithotrophy in other polychaete families, and leads to the proposal that larval development in terebellids has been constrained during the evolution of the lineage. The results of this study demonstrate that generalizations regarding complex relationships among life history traits are often inappropriate. The need for more comparative studies of marine invertebrate reproduction and development, and the integration of phylogenetic analyses into the study of life history evolution in marine invertebrates is highlighted.

\section{Introduction}

The great diversity of reproductive and developmental modes exhibited by marine invertebrates presents a chal- 
lenge to evolutionary biologists who seek patterns and trends in life histories. Responses have included models of optimal combinations of life history traits (e.g., Vance, 1973; Christiansen and Fenchel, 1979; Roughgarden, 1989), and theoretical arguments and experimental tests on the adaptive significance of certain traits (e.g., Thorson, 1950; Chia, 1974; Pechenik, 1979; Doyle and Hunte, 1981; Sinervo and McEdward, 1988; Strathmann, 1985; Grant, 1990; Hart, 1992). Several hypotheses regarding the associations between traits have also been investigated using specific cases (e.g., Strathmann et al., 1984; Kabat, 1985; Hess, 1993). However, only a few studies have undertaken statistical analyses of comparative data to assess the covariation of life history traits in marine invertebrate groups (Hines, 1982; Buroker, 1985; Olive, 1985; Emlet et al., 1987; McEdward and Chia, 1991). This contrasts with the numerous investigations into life history evolution of vertebrates, in which the comparative approach has clearly identified relationships among life history traits, and has documented biological constraints and phylogenetic effects on the evolution of life histories (e.g., Trendall, 1982; Stearns, 1983, 1984a, b; Dunham and Miles, 1985; Harvey and Clutton-Brock, 1985; Gittleman, 1986; Saether, 1988; Miles and Dunham, 1992).

While the range of reproductive modes in most marine invertcbrate phyla is well known, lifc history data arc scattered and in many cases incomplete, so that comparative data sets are rare. In this study, I combine data from autecological investigations of terebellid polychaetes with my own results for four terebellid species from the west coast of North America to construct a data matrix of life history traits for the family Terebellidae. Despite large variations in size, the body organization is relatively homogenous among all the genera in the family. This feature, as well as the fact that no feeding larvae have been reported in this group, means that the comparisons made in the present study will not be complicated by the covariation of traits with different body forms or different larval nutrition mechanisms. Nonetheless, it is obvious from previous studies of terebellids [Nicolea zostericola (Eckelbarger, 1974, 1975, 1976), Neoleprea streptochaeta (Duchêne, 1979), Thelepus setosus (Duchêne, 1980, 1991), Eupolymnia nebulosa (Grémare, 1986; Bhaud et al., 1987; Bhaud and Grémare, 1988; Bhaud, 1991), Lanice conchilega (I Ieimler, 1981; Bhaud, 1988, 1991; Smith, 1989a, b), and Ramex californiensis (Blake, 1991)], that the Terebellidae, like many other polychaete families, exhibit a high degree of heterogeneity in terms of reproduction and development (Wilson, 1991).

The following life history traits were investigated in Eupolymnia crescentis Chamberlin, 1919, Neoamphitrite robusta (Johnson, 1901), Thelepus crispus Johnson, 1901, and Ramex californiensis Hartman, 1944, and gathered from previously published accounts of several other ter- ebellid species: (1) mode of reproduction, i.e., free spawning, extratubular brooding or intratubular brooding; (2) body size, i.e., maximum body length; (3) maximum oocyte size; (4) maximum fecundity, i.e., maximum number of full-grown oocytes in free spawning species, or maximum number of larvae in a single brood in brooding species; (5) mode of development, i.c., planktonic, mixed, or direct development; (6) stage at juvenile, i.e., the number of setigers present when larvae begin to feed on the adult diet; (7) duration of the breeding season; and (8) breeding strategy, i.e., iteroparous or semelparous. These data were analyzed to reveal the covariation of life history traits in the Terebellidae, and comparisons were made with other polychaetes and marine invertebrates in general. The possible limitations on life history evolution in the Terebellidae, imposed either by ancestry or design, were also examined, and the need for a phylogenetic analysis of the group discussed.

\section{Materials and Methods}

\section{Species}

Eupolymnia crescentis, which ranges from Alaska to western Mexico, is common in sandy mud sediments of bays and estuaries of the California coast. Neoamphitrite robusta, which is distributed from Alaska to California, is also found in abundance in mud and under rocks of the intertidal zone of the central California coast. Thelepus crispus is found in tubes of coarse sand and gravel attached to the undersides of rocks in the intertidal from Alaska to southern California. Apart from the observation that $T$. crispus spawns yellow-orange oocytes onto the sediment surface in July and August on San Juan Island, Washington (Strathmann, 1987), the reproduction and development of these three common species have remained undescribed. The larval development of the fourth species, Ramex californiensis, which is restricted in its distribution to the central California coast, is known (Blake, 1991). I have supplemented the observations of Blake (1991) to provide more information about the reproductive biology of this species.

\section{Reproductive mode}

The reproductive mode refers to the degree of parental care provided to fertilized eggs. Eggs may be free spawned to give rise to planktonic larvae, or larvae may be brooded either within the maternal tube or in a gelatinous mass outside the tube. Each species was assigned a reproductive mode according to observations made in the field or in the lab.

\section{Body size}

Maximum body length of each species was recorded from personal observations or from the literature. Length 
was chosen as a measure of body size because of its correlation with body volume (e.g., T. crispus: $\mathrm{r}^{2}=0.88, n$ $=17, P<0.001$ ), and because it is a parameter that is often reported for terebellids in the literature.

\section{Length of breeding season}

Between April 1990 and May 1992, E. crescentis and N. robusta were collected intertidally from Bodega Harbor, California. Monthly samples were fixed in 10\% seawaterbuffered formalin and preserved in $70 \%$ ethanol. The coelomic contents from up to 10 females from each sample were examined, and the maximum diameters of $80 \mathrm{oo-}$ cytes from each female were measured at $100 \times$ magnification. A year-long time series of oocyte size frequency histograms was constructed for each species to show the pattern of oocyte development and likely breeding season for the population. Oocyte diameter data were log transformed before analysis of variance (ANOVA) to examine the degree of synchrony among samples throughout the year, and among females in each sample; Scheffés post hoc test was used to clarify the reasons for any significant differences (Sokal and Rohlf, 1981). The reproductive period of each species was confirmed by spawning observations in the lab, and by qualitative observations of coelomic contents during a second reproductive season.

$R$. californiensis was sampled intertidally from Dillon Beach, California, almost every month from August 1990 to February 1992. The worms were fixed and preserved as described above, and oocyte size frequency histograms were constructed for bimonthly intervals from August 1990 to June 1991. The number of oocytes in each female was small, therefore all the oocytes found in each female were measured. The presence of broods in tubes from the monthly collections was also noted. Thelepus crispus was observed in the field and collected from a variety of locations on San Juan Island, Washington, from July to December, 1991. The presence of egg masses in the field and in the lab was recorded during this time to estimate the length of the reproductive period.

\section{Maximum oocyte size and fecundity}

Maximum oocyte size was recorded from coelomic samples of mature females of each species, and estimates of fecundity for $E$. crescentis and $N$. robusta were made as follows. The number of oocytes in three 2-ml subsamples from a $250-\mathrm{ml}$ suspension of all oocytes removed from weighed, mature females were counted. An estimate of the total number of oocytes in each worm was then extrapolated from the mean number in the subsamples. To estimate fecundity in $R$. californiensis, the number of larvae were counted in all cocoons taken from five tubes from each of three months (April, May, and June, 1991); as the cocoons of $R$. californiensis are deposited as se- quential broods rather than simultaneously, maximum fecundity was recorded as the highest number of larvae in a single cocoon, i.e., the maximum number of larvae in one brood. In T. crispus, a single brood consists of paired, elongated egg masses that are attached to the maternal tube. Entire broods collected in the field in July and October 1991 were blotted and weighed, and the number of embryos in a weighed subsample of each brood was counted. This number was extrapolated to give an estimate of the number of larvae in an entire brood.

\section{Mode of development}

Several adults of $E$. crescentis spawned spontaneously in seawater tables at Bodega Marine Laboratory, California, following collection on August 9, 1991. On August 13 , other adults were placed in individual finger bowls in $0.2 \mu \mathrm{m}$ filtered seawater and induced to spawn by increasing the seawater temperature by about $8^{\circ} \mathrm{C}$ over one hour in direct sunlight, followed by flushing with ambient temperature seawater $\left(\sim 16^{\circ} \mathrm{C}\right)$. Fertilizations were made in $0.2 \mu \mathrm{m}$ filtered seawater and larvae were maintained at Long Marine Laboratory, California, at about $16^{\circ} \mathrm{C}$ with regular water changes. Settled larvae were transferred to $100 \mu \mathrm{m}$ filtered seawater, and raised in dishes that were covered with microbial films.

Although individuals of $N$. robusta spawned occasionally in the lab during May 1991, attempts to induce synchronous spawning of males and females during two reproductive periods (May, 1991; April and May, 1992) failed. Development in $R$. californiensis has been described by Blake (1991), and was also monitored in October and November, 1990, in this study. Embryos were collected in the field, or from cocoons laid in the lab. Worms and cocoons were maintained in small petri dishes with some sand and nitex mesh in $5 \mu \mathrm{m}$ filtered seawater at about $14^{\circ} \mathrm{C}$. For $T$. crispus, development was recorded in October and November, 1991, from broods collected on San Juan Island and raised at Friday Harbor Laboratories, Washington, in $64 \mu \mathrm{m}$ filtered seawater at about $11^{\circ} \mathrm{C}$.

\section{Comparative data}

Data on the reproduction and development of seven other terebellids were collected from the literature. When available, the following life history traits were recorded for each species: (1) mode of reproduction, i.e., free spawning, extratubular brooding or intratubular brooding; (2) maximum body length ( $\mathrm{mm}$ ); (3) maximum diameter $(\mu \mathrm{m})$ of coelomic oocytes; (4) maximum fecundity, i.e., maximum number of full grown oocytes in free spawning species, or maximum number of larvae in a single brood in brooding species; these data vary over several orders of magnitude and therefore were log transformed for sta- 
tistical analyses; (5) number of days larvae spend in the plankton; (6) stage at juvenile, i.e., the number of setigers present on larvae when they begin to feed on the adult diet; (7) duration of the breeding season (months); and (8) breeding strategy, i.e., iteroparous or semelparous. The relationships between these traits in the family Terebellidae were examined using a correlation matrix. ANOVA was used to determine whether traits differed significantly among the reproductive modes, and multiple regression analysis was used to examine the covariation of some traits when body size is held constant.

\section{Results}

\section{Present study}

Reproductive mode. Eupolymnia crescentis and Neoamphitrite robusta are both broadcast spawners, as shown by their free-spawning behavior in the lab during July and August, 1991, and May, 1991, respectively. Moreover, no brooded larvae were ever found in the field. Thelepus crispus and Ramex californiensis, on the other hand, are both brooders. Females of $T$. crispus were collected in the field with several elongated egg masses attached to the interior of the tube. Ramex californiensis sequentially lays small cocoons along the length of the inner tube wall.

Body size. The maximum body length of the four species ranges from $25 \mathrm{~mm}$ in $R$. californiensis to $280 \mathrm{~mm}$ in $T$. crispus; $E$. crescentis measures up to $130 \mathrm{~mm}$, and $N$. robusta has a maximum length of $250 \mathrm{~mm}$ (Hartman, 1969 ; pers. obs.). Using the volume of a cone $\left(1 / 3 \pi r^{2} h\right)$ as an cstimatc of body volume, with body length $=h$ and body width $=2 \mathrm{r}$, the order of body sizes among the four species remains the same ( $R$. californiensis: $\sim 26 \mathrm{~mm}^{3}$; E. crescentis: $\sim 3400 \mathrm{~mm}^{3} ; N$. robusta: $\sim 11,000 \mathrm{~mm}^{3}$; T. crispus: $\sim 12,400 \mathrm{~mm}^{3}$ ).

Length of breeding season. Figure 1 shows the oocyte size frequency histogram for $E$. crescentis from April 1990 to March 1991. Oocytes grow rapidly from about $50 \mu \mathrm{m}$ in April to begin to accumulate as full-grown oocytes of about $180 \mu \mathrm{m}$ in diameter from late May, until there is a single peak around $185 \mu \mathrm{m}$ in August (Fig. 1). The annual spawning period of $E$. crescentis at Bodega Harbor is from July through September, as is indicated from the histograms and confirmed by observations of spawning in the lab; although no sample is available for September 1990, mature females were present in a sample taken in September 1991. No coelomic oocytes were observed in the post-spawning population in October 1990, and it is not until January 1991 that proliferation of primary oocytes begins again. Development from small primary oocytes released into the coelom to full grown oocytes takes from five to eight months in this species. ANOVA tests show significant differences in mean oocyte diameter

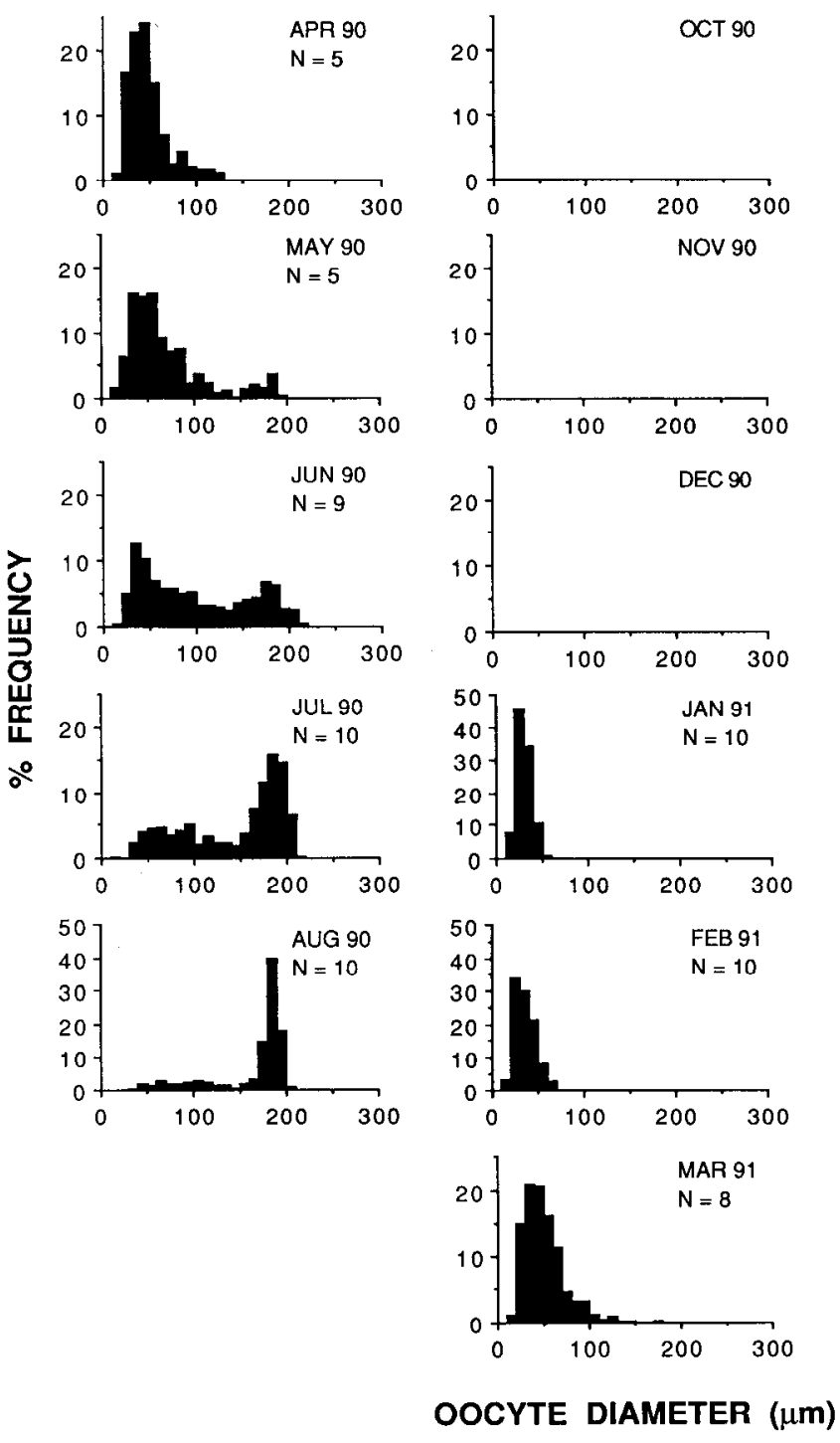

Figure 1. Monthly size-frequency histograms of maximum oocyte diameter for Eupolymnia crescentis from Bodega Harbor, California, from April 1990 to March 1991. No sample was available for September 1990; 15 worms were examined in each sample from October, November, and December, 1990, but no gametes were seen. N, number of females in each sample.

among females in monthly samples (e.g., June, 1990: $\mathrm{F}$ $=6.295, \mathrm{df}=8, P<0.0001 ;$ July, 1990: $\mathrm{F}=11.50, \mathrm{df}$ $=9, P<0.0001 ;$ August, 1990: $\mathrm{F}=12.34$, $\mathrm{df}=9, P$ $<0.0001$ ). However, multiple comparison tests reveal that in August, 1990, the month in which the highest proportion of full-grown oocytes are present in the population, nine of the ten females did not differ significantly in their mean oocyte diameter.

Neoamphitrite robusta shows a different pattern of reproduction in which oogenesis takes a full year, from May to the following April, and mature females with large, full-grown oocytes are present in the population from 

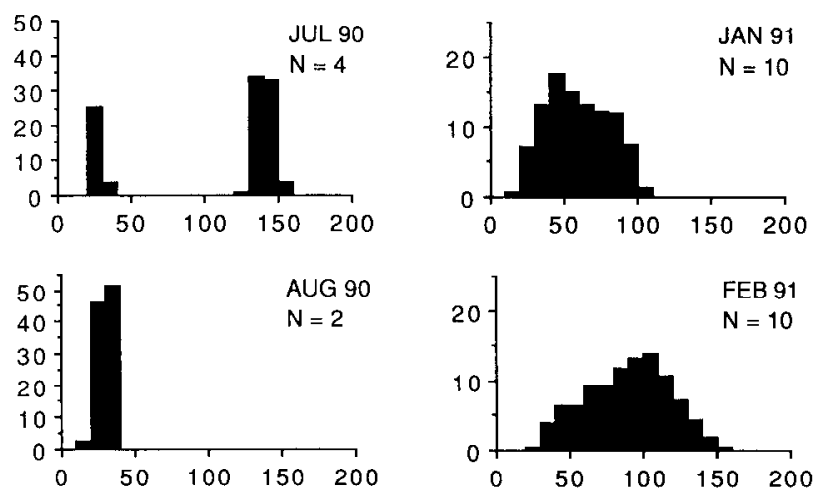

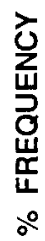
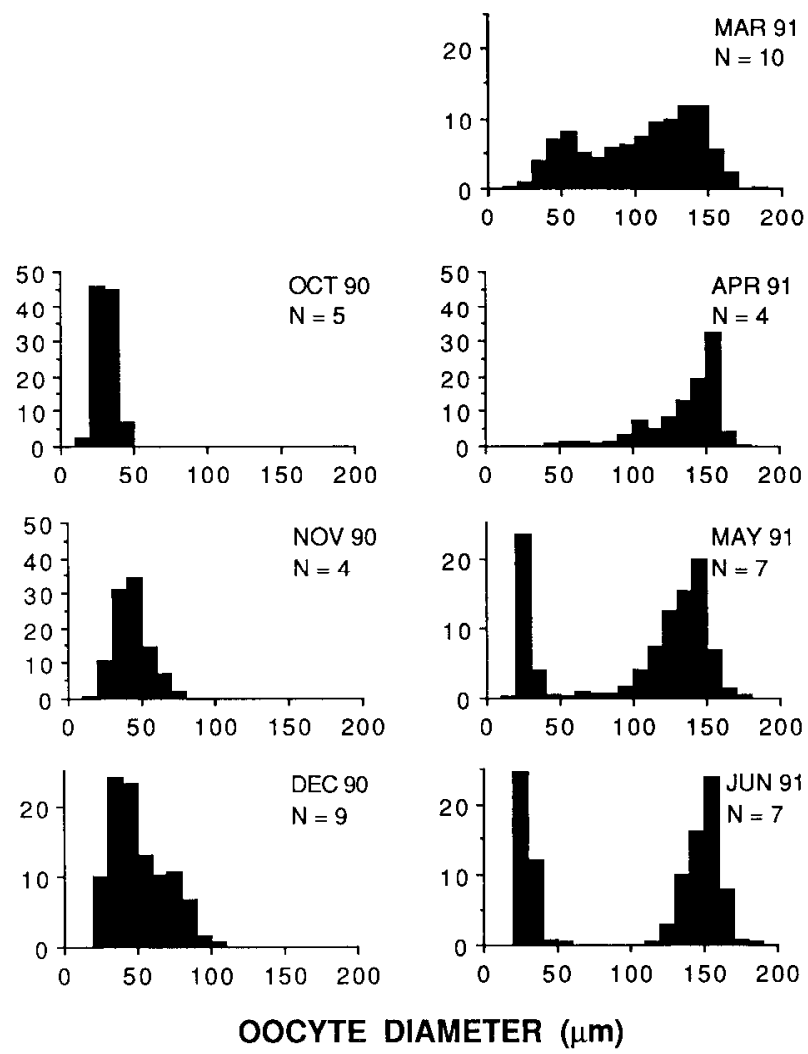

Figure 2. Monthly size-frequency histograms of maximum oocyte diameter for Neoamphitrite robusta from Bodega Harbor, California, from July 1990 to June 1991. The bimodal peaks for May and June, 1991, and July 1990, reflect differences in oocyte size-frequency distributions among worms in the samples, not within worms. No sample was available for September 1990. N, number of females in each sample.

April through July (Fig. 2). This breeding season coincides with the spawning of some individuals in the lab during May 1991. In the oocyte size frequency histograms for July 1990 through June 1991, July 1990 represents the end of the spawning period. In that sample, a single mature female accounts for the peak of large oocytes, and three other worms in the sample contain a few small oocytes. By August 1990, only two worms out of nine examined contained any gametes, and they each had only very early stage oocytes. Proliferation of primary oocytes continues in the population from May to March, with steady growth from October into full grown oocytes and spawning the following April through July (Fig. 2). ANOVA tests show significant differences in mean oocyte diameter among females in the monthly samples (e.g., October 1990: F $=13.70, \mathrm{df}=4, P<0.0001 ;$ February 1991: $\mathrm{F}=12.24$, $\mathrm{df}=9, P<0.0001 ;$ June 1991: $\mathrm{F}=109.80, \mathrm{df}=6, P$ $<0.0001$ ), and multiple comparison tests confirm that oogenesis is not tightly synchronized among females at any time throughout the year. Bimodal distributions of oocytes appear in the May and June 1991 samples, and also in the July 1990 sample (Fig. 2). However, in each case, the peak of smaller oocyte sizes is fully accounted for by two or three females that have only $10-30 \mu \mathrm{m}$ diameter oocytes in the coelom.

In $R$. californiensis, bimonthly samples of females from Dillon Beach all show a wide range of oocyte sizes throughout the year; in each sample there is skewing towards smaller oocytes, with just a small proportion of oocytes $>300 \mu \mathrm{m}$ in diameter present (Fig. 3). Intratubular cocoons of larvae of $R$. californiensis were found in samples from every month sampled between June 1990 and February 1992; in many cases females were still with the broods, and they always contained oocytes of various sizes in their coeloms. While the larvae within each cocoon were at the same development stage, the stages of larval development differed among cocoons in a tube, indicating that the cocoons were laid sequentially.
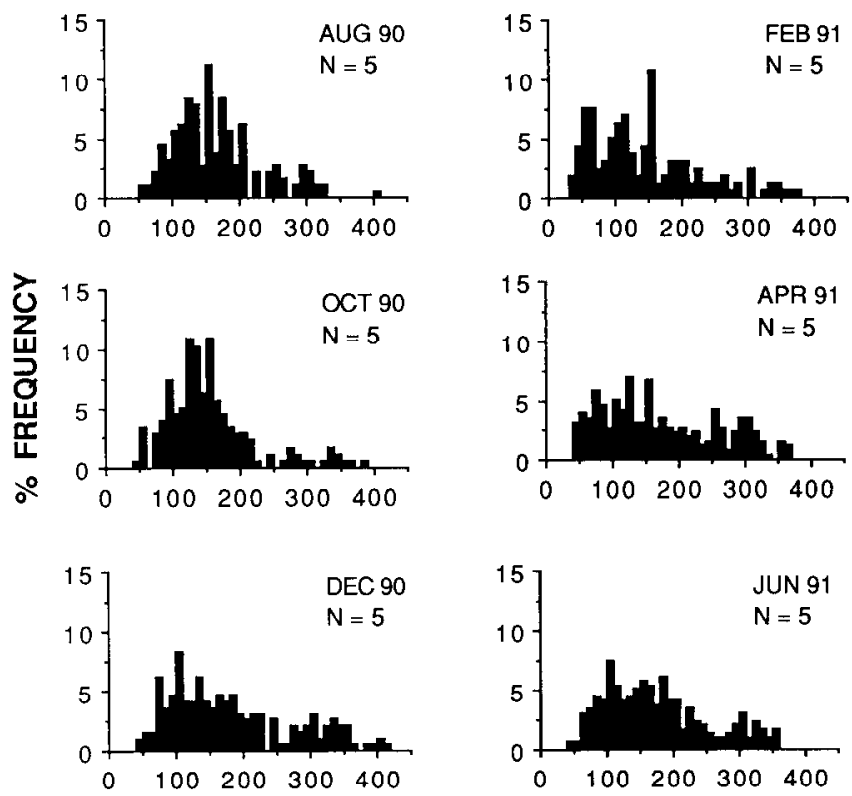

OOCYTE DIAMETER $(\mu \mathrm{m})$

Figure 3. Bimonthly size-frequency histograms of maximum oocyte diameter for Ramex californiensis from Dillon Beach, California, from August 1990 to June 1991. N, number of females in each sample. 
Table I

Maximum coelomic oocyte diameter and maximum fecundity recorded for Eupolymnia crescentis, Neoamphitrite robusta, Ramex californiensis, and Thelepus crispus

\begin{tabular}{lcc}
\hline \hline & $\begin{array}{c}\text { Maximum } \\
\text { oocyte size }(\mu \mathrm{m})\end{array}$ & $\begin{array}{c}\text { Maximum fecundity } \\
(\mathrm{n} ; \overline{\mathrm{X}} \pm \text { S.E. })\end{array}$ \\
\hline Eupolymnia crescentis & 210 & $\begin{array}{c}128,500 \\
\text { Neoamphitrite robusta }\end{array}$ \\
Ramex californiensis & 180 & $(6 ; 105,430 \pm 12,951)$ \\
829,833 \\
Thelepus crispus & 410 & $(5 ; 404.799 \pm 109,338)$ \\
& 400 & $\begin{array}{c}44 \\
(15 ; 29 \pm 2.4) \\
51,555\end{array}$ \\
& & $(4 ; 28,582 \pm 11,796)$ \\
\hline
\end{tabular}

${ }^{\dagger}$ Fecundity in $E$. crescentis and $N$. robusta is the total number of oocytes in gravid females; fecundity in $R$. californiensis and T. crispus is the number of larvae in a single brood, i.e., a single cocoon in $R$. californiensis, or a single mass of elongated egg sacs in $T$. crispus; $\mathrm{n}$, sample size; $\overrightarrow{\mathrm{X}} \pm$ S.E., mean \pm standard error.

Intratubular egg masses of $T$. crispus were observed in the field in July, October, and November of 1991, and have also been reported in August (Strathmann, 1987). Egg masses were also laid in the lab in November and December of 1991. It appears then that $T$. crispus breeds for at least six months from July to December, and perhaps longer.

Maximum oocyte size and fecundity. In all four species, oocytes change from a spherical to a discoid shape as they develop in the coelom, and they round out again when spawned. Table I shows the maximum oocyte diameter recorded from coelomic samples of each species. Ramex californiensis and $T$. crispus have the largest oocyte sizes, at 410 and $400 \mu \mathrm{m}$, respectively, while $N$. robusta has the smallest $(180 \mu \mathrm{m})$; the maximum oocyte size in $E$. crescentis is $210 \mu \mathrm{m}$. The maximum fecundity ranges from 44 in a single cocoon of $R$. californiensis, to 829,833 full- grown oocytes in a mature $N$. robusta female, with $T$. crispus and $E$. crescentis having maximum fecundities of 51,555 and 128,500, respectively (Table I). The high degree of variation in fecundity of each species is due to body size differences among females in each sample. In Table II total spawn or brood volume is expressed as a percentage of total body volume for the four species. This crude estimate shows that reproductive output (percent of total body volume given to a single brood or spawn) in the worms ranges from about $2.37 \%$ in $R$. californiensis to about $8.60 \%$ in $N$. robusta. E. crescentis and $T$. crispus have values of about $6.67 \%$ and $5.88 \%$, respectively.

Mode of development. Table III summarizes the larval development of E. crescentis at about $16^{\circ} \mathrm{C}$. Twenty-four hours after fertilization, the larva is about $150 \mu \mathrm{m}$ long, fully ciliated and free swimming, and has two red eyespots. By about $48 \mathrm{~h}$, the $\sim 200 \mu \mathrm{m}$-long trochophore stage is reached; the larva possesses an apical tuft, a wide prototrochal band, a telotroch, and a neurotroch. During the third day of development, surface constrictions indicate the onset of segmentation, and the first pair of hooded setae appear. By the end of the third day, larvae possess a pair of hooded setae on each of two segments. Setae and setigers are continually added as outlined in Table III. The ciliated mouth appears when the larvae are about 5 days old and approximately $350 \mu \mathrm{m}$ long. At this stage the gut outline is already visible, but yolk granules are still found in the gut and body cavity, and it is not until the larva is about 7 days old that the mouth and gut become fully functional. At this stage the larva possesses five setigers, the posterior four of which bear a pair of uncini. The telotroch is lost and the neurotroch is reduced to a ciliary patch behind the mouth. Up to this point in their development the larvae have been mainly near the bottom, and they are not very active swimmers. After this stage, the juveniles crawl around, feeding on microbial films on the bottom of the culture dishes. By 21 days the first tentacle bud is $100 \mu \mathrm{m}$ long, there are eight setigers, and the first pair of nephridia has begun to develop.

Table II

Estimates of reproductive output for Eupolymnia crescentis, Neoamphitrite robusta, I helepus crispus, and Ramex californiensis

\begin{tabular}{lcccc}
\hline \hline & $\begin{array}{c}\text { Single oocyte } \\
\text { volume }{ }^{\mathrm{a}}\left(\mathrm{mm}^{3}\right)\end{array}$ & $\begin{array}{c}\text { Total oocyte } \\
\text { volume }^{\mathrm{b}}\left(\mathrm{mm}^{3}\right)\end{array}$ & $\begin{array}{c}\text { Total body } \\
\text { volume }^{\mathrm{c}}\left(\mathrm{mm}^{3}\right)\end{array}$ & $\begin{array}{c}\frac{\text { Total oocyte volume }}{\text { Total body volume }} \times 100 \\
(\%)\end{array}$ \\
\hline $\begin{array}{l}\text { Eupolymnia crescentis } \\
\text { Neoamphitrite robusta }\end{array}$ & $1.766 \times 10^{-3}$ & $2.270 \times 10^{2}$ & $3.403 \times 10^{3}$ & 6.67 \\
Ramex californiensis & $1.150 \times 10^{-3}$ & $9.544 \times 10^{2}$ & $11.062 \times 10^{3}$ & 8.60 \\
Thelepus crispus & $14.137 \times 10^{-3}$ & 0.622 & 26.180 & 2.37 \\
\hline
\end{tabular}

Reproductive output is expressed as the percentage of total body volume that is given to free-spawned or brooded eggs in a single reproductive event. $a=4 / 3 \pi r^{3}$, where $2 r$ is the diameter of a spawned, spherical oocyte in each species; $b=a \times$ fecundity in each species (see Table I); $c=1 / 3 \pi^{2} h$, where $2 \mathrm{r}$ is the maximum width, and $\mathrm{h}$ is the maximum length of each species. 
Table III

Development of Eupolymnia crescentis larvae raised at approximately $16^{\circ} \mathrm{C}$ in August 1991

\begin{tabular}{cc}
\hline $\begin{array}{c}\text { Days after } \\
\text { spawning }\end{array}$ & Stage of development \\
\hline 1 & $150 \mu \mathrm{m}$ ciliated larva; 2 red eyespots appear. \\
2 & $200 \mu \mathrm{m}$ long trochophore larva with apical tuft, a wide prototroch and telotroch; neurotroch also present, and intersecting the \\
telotroch; first segmental constriction appears.
\end{tabular}

The development of $T$. crispus is summarized in Table IV. In this species, larvae hatch from the intratubular egg mass as $350 \mu \mathrm{m}$ long, one-setiger larvae. While hatching from an egg mass is not tightly synchronized among all larvae, newly hatched larvae are usually at this stage of development. The prototroch, telotroch, and neurotroch are well developed, and there are two eyespots; there is no apical tuft and segmental ciliary bands are absent. Up to the second day post-hatching, larvae have limited swimming abilities, and thereafter they remain on the bottom of the container. The second setiger develops on the third day, and by day four there are three setigers. At 7 days, the prototroch and telotroch have been lost from the 4-setiger larvae, and the neurotroch begins to recede from the posterior end leaving only segmental patches of cilia by day 12 . At this stage there are five setigers, each with two pairs of capillary setae. In eight-setiger stages the gut is fully functional and the juveniles form mucus tubes to which sediment particles adhere.
Observations of development in $R$. californiensis in the present study are generally similar to those reported by Blake (1991); larvae undergo direct development, and emerge as eight-setiger, crawl away larvae with three to five tentacles. The mouth and gut become functional at the 11- to 12-setiger stage, approximately 15 days after hatching.

\section{Comparative data}

Data on reproductive and developmental traits of seven other terebellid species were available in the literature. Combined with the data from the present study, the traits of three intratubular brooders, three extratubular brooders, and six broadcast spawners are represented in Table $\mathrm{V}$ [one species, Eupolymnia nebulosa, is reported as an extratubular brooder in the Mediterranean and as a broadcast spawner in the English Channel (Grémare, 1986; Bhaud et al., 1987)]. There are 11 species from 9 genera represented in the matrix.

Table IV

Development of Thelepus crispus larvae raised at approximately $14^{\circ} \mathrm{C}$ in October and November 1991

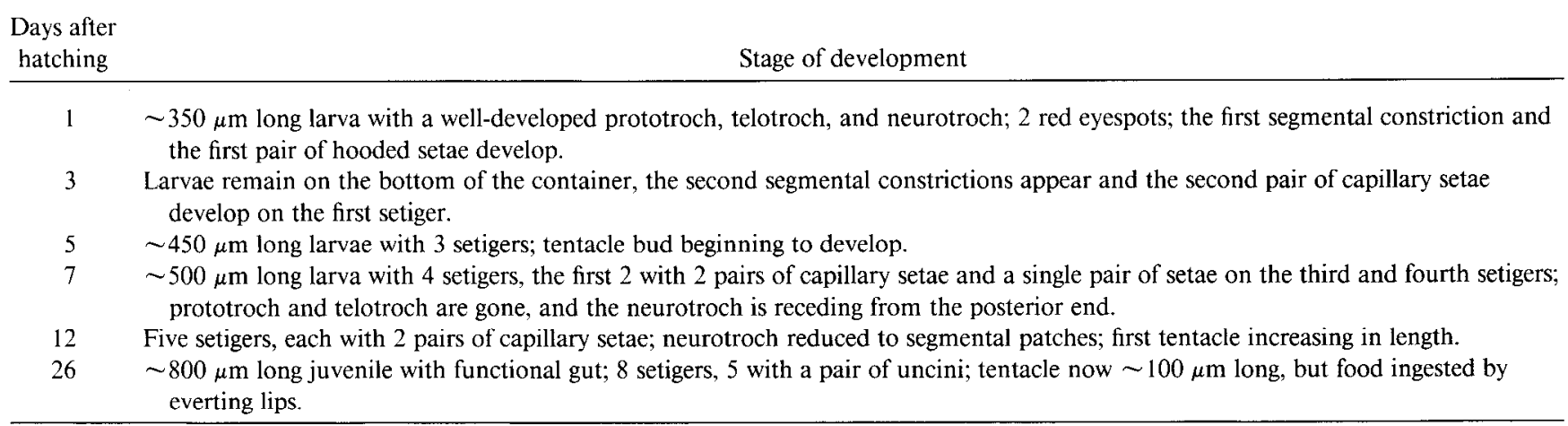


D. $\mathrm{MCHUGH}$

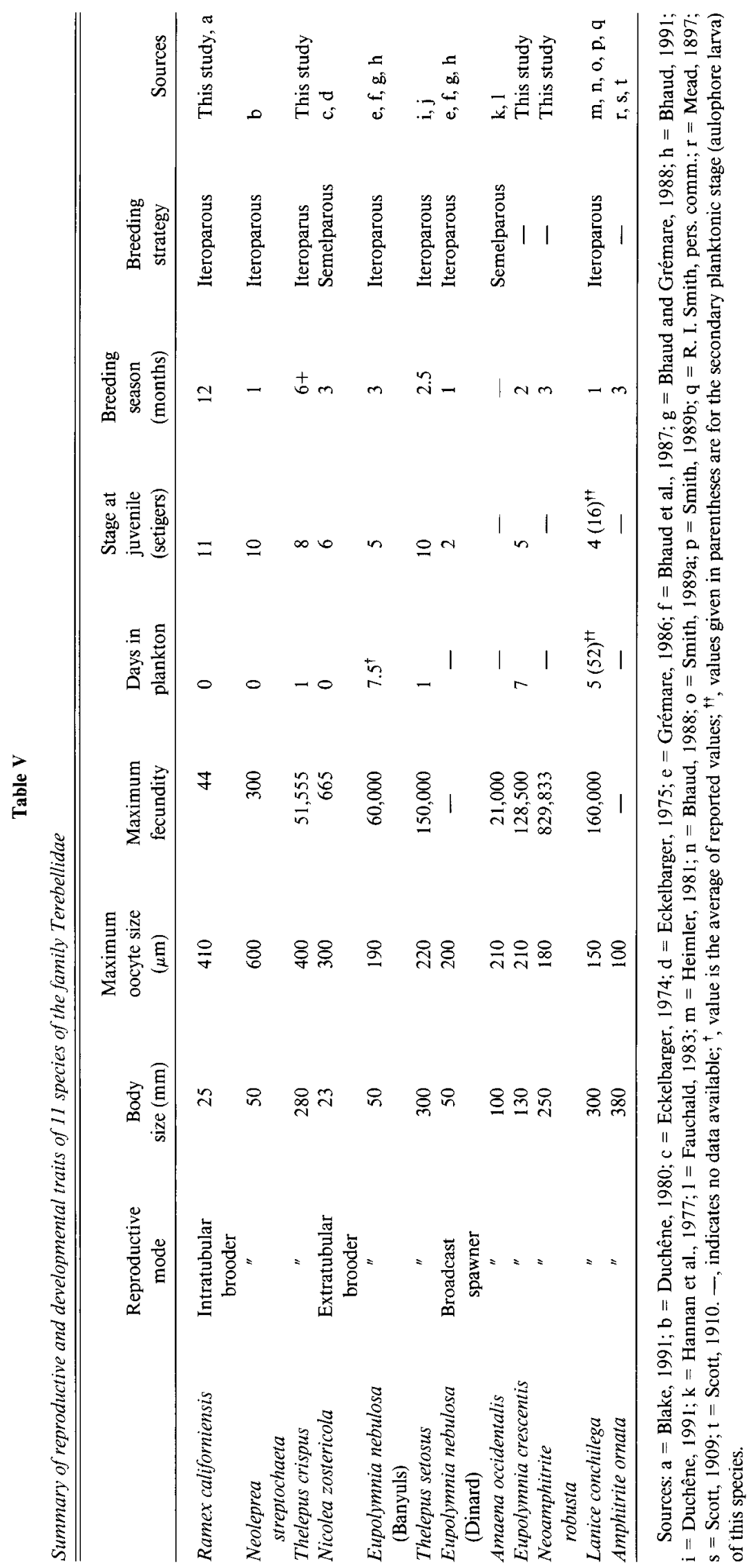




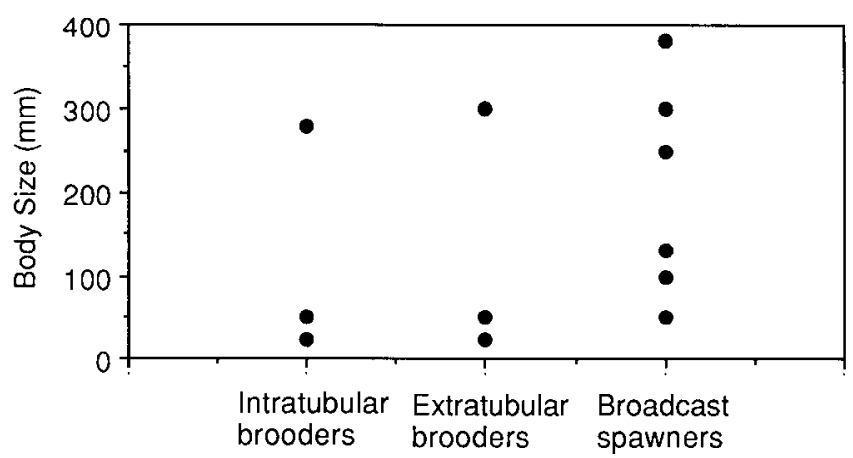

Figure 4. The reproductive modes of terebellids graphed against body size (length in $\mathrm{mm}$ )

Size ranges from 23 to $380 \mathrm{~mm}$ among all species, with no significant difference in body size among reproductive modes $(\Gamma=0.518, \mathrm{df}=11, P<0.612)$. Indeed, as Figure 4 illustrates, each of the three reproductive modes are represented in species of vastly differing body sizes. ANOVA reveals a statistically significant difference in the maximum oocyte size among the three reproductive modes $(\mathrm{F}=19.33, \mathrm{df}=11, P<0.0006)$. The smallest oocyte sizes are associated with the six broadcast spawners, while the largest ones are those of species that brood their larvae in the maternal tube. Fecundity ranges over several orders of magnitude among the species in the study, with the two extremes being $R$. californiensis (44) and $N$. robusta $(829,833)$. While log of fecundity does not differ significantly among the three reproductive modes $(\mathrm{F}$ $=3.039, \mathrm{df}=9, P<0.112$ ), it does differ between brooders with direct development and those with a planktonic stage during development $(\mathrm{F}=108.03$, $\mathrm{df}=5, P<0.0091)$.

Three of the species in the study undergo direct development, and in the five species for which planktonic development is known, the larvae remain in the plankton from 1 to about 7.5 days. The length of the planktonic period does not differ according to reproductive mode ( $\mathrm{F}$ $=3.07$, df $=7, P<0.134)$, but the stage at which the larval gut becomes fully functional and exogenous food supplies are taken in (i.e., number of setigers at initial juvenile stage) does $(\mathrm{F}=6.97 \mathrm{df}=8, P<0.027)$. Larvae from intratubular brooders become independent from yolk supplies at a more developed stage (up to 11 setigers in $R$. californiensis) than either extratubular brooders (510 setigers) or broadcast spawners (2-5 setigers).

Free-spawning species and extratubular brooders generally have short, discrete breeding seasons, while two of the intratubular brooding species reproduce continuously for extended periods. However, the length of the breeding season does not differ significantly according to reproductive mode $(\mathrm{F}=2.25, \mathrm{df}=10, P<0.167)$. Only two species, Nicolea zostericola and Amaeana occidentalis, are reported to be semelparous; six others are iteroparous.

The matrix of correlation coefficients for the life history traits is shown in Table VI. It shows that fecundity covaries directly with body size, and inversely with egg size. However, there is no significant relationship between body size and oocyte size, and multiple regression analysis shows that egg size does not predict fecundity if body sizc is held constant $\left(\mathrm{F}_{(2,5)}=3.390, P<0.117\right)$. Juvenile stage covaries directly with egg size, and inversely with the length of the planktonic period during development. While the relationship is not significant $(P<0.054)$, there is a definite trend towards decreasing planktonic period with increasing egg size. No other correlations among traits are statistically significant.

\section{Discussion}

\section{Present study}

The four species in the present study span the range of reproductive and developmental modes recorded for the family Terebellidae. Eupolymnia crescentis and Neoamphitrite robusta are both free-spawning terebellids with reproductive periods lasting approximately three months. Interestingly, these two co-occurring species differ in their timing of primary oocyte release, the pattern of oocyte growth, and the timing of spawning. Environmental stimuli control primary oocyte release and rate of oocyte

Table VI

Correlations between reproductive and developmental traits among species of the family Terebellidae

\begin{tabular}{|c|c|c|c|c|c|c|}
\hline & Body size & $\begin{array}{l}\text { Maximum } \\
\text { oocyte size }\end{array}$ & $\begin{array}{l}\text { Maximum } \\
\text { fecundity }\end{array}$ & $\begin{array}{l}\text { Days in } \\
\text { plankton }\end{array}$ & $\begin{array}{l}\text { Stage at } \\
\text { juvenile }\end{array}$ & Breeding season \\
\hline Body size & 1 & & & & & \\
\hline Maximum oocyte size & -0.449 & 1 & & & & \\
\hline Maximum fecundity & $\underline{0.747}$ & $-\underline{0.743}$ & 1 & & & \\
\hline Days in plankton & $\overline{0.106}$ & -0.699 & 0.671 & 1 & & \\
\hline Stage at juvenile & 0.053 & $\underline{0.698}$ & -0.581 & $-\underline{0.778}$ & 1 & \\
\hline Breeding season & -0.177 & $\overline{0.312}$ & -0.523 & $-\overline{0.389}$ & 0.570 & 1 \\
\hline
\end{tabular}

$P<0.05$ for underlined values. 
growth in some polychaetes (see Olive, 1984). However, without further study, it is not possible to speculate on how the same environmental stimuli affect $E$. crescentis and $N$. robusta so differently. While reproduction in $E$. crescentis and $N$. robusta populations is not tightly synchronized, fertilization efficiency in these species could potentially be enhanced by the stimulation of conspecifics by spawning individuals, as apparently happened with $E$. crescentis in the lab in August, 1991. Such an effect would presumably be greater in $E$. crescentis, which reaches densitics of 3 animals per $10 \mathrm{~cm}^{2}$ at Bodega Harbor; $N$. robusta is patchy in its distribution, usually occurring in small groups of several adults.

The maximum egg sizes in $E$. crescentis and $N$. robusta, 210 and $180 \mu \mathrm{m}$, respectively, are within the range associated with lecithotrophy in polychaetes generally (Schroeder and Hermans, 1975), and are very similar to those reported for other free spawning terebellids, Eupolymnia nebulosa (Grémare, 1986) and Amaeana occidentalis (Hannan et al., 1977). The number of eggs produced by $E$. crescentis in a single reproductive period is substantially larger than that of $A$. occidentalis, which has a similar body size and egg size (Fauchald, 1983). Fecundity of $N$. robusta is very high compared to reports for other terebellids, and other lecithotrophic polychaetes (Grémare and Olive, 1986), although it should be noted that fecundity is rarely reported for large, free-spawning species.

Larval development in E. crescentis is planktonic and non-feeding, and corresponds generally with the primary planktonic larval development of Lanice conchilega (Heimler, 1981). Like L. conchilega, E. crescentis has a demersal metatrochophore, but $E$. crescentis larvae are not good swimmers. Although the dispersal of $E$. crescentis larvae over the seven-day planktonic period observed in this study might be expected to be substantial, it may be restricted due to the habitat of the species. Like many terebellids (Day, 1967; Bhaud, 1991), E. crescentis is found in quiet bays where fine sediments are deposited, areas in which offshore/alongshore currents may not exert great influences on larval dispersal. The common high population densities of E. crescentis (e.g., Bodega Harbor, California, and South Slough, Oregon) could result from the retention of larvae in the parental habitat. While attempts to raise larvae of $N$. robusta during the present study were unsuccessful, it is predicted, with a maximum egg size of $180 \mu \mathrm{m}$ and broadcast spawning, that $N$. robusta undergoes development similar to $E$. crescentis, with a comparable planktonic period.

The two brooders in the study, Ramex californiensis and Thelepus crispus, both brood their larvac in the maternal tube. These two species represent the extremes in body size in this study, 25 and $280 \mathrm{~mm}$, respectively, and the presence of brooding in a worm as large as $T$. crispus is unexpected (see discussion below). Despite the great differences in body size, these two species share a number of life history traits. Both reproduce continuously, $R$. californiensis year round and $T$. crispus for at least six months. Continuous year-round breeding has never been reported in a terebellid before, although it is known in other brooding polychaetes, for example, the ampharetid Hypaniola kowalewskii (Marinescu, 1964). The extratubular brooding terebellids, Nicolea zostericola, Eupolymnia nebulosa, and Thelepus setosus breed over three to four months, but only a single batch of oocytes is produced annually in these species (Eckelbarger, 1975; Bhaud et al., 1987; Duchêne, 1991). This contrasts with R. californiensis in which females with broods of larvae have oocytes of all developmental stages present in the coelom at all times of the year. While oogenesis in T. crispus was not monitored from month to month, those females found with broods also had oocytes of all sizes in the coelom.

Ramex californiensis and T. crispus have very similar maximum oocyte sizes, 410 and $400 \mu \mathrm{m}$, respectively. Such large eggs are typical of brooding polychaetes (Schroeder and Hermans, 1975) and of some brooding terebellids; however, they are substantially smaller than the maximum egg size of $600 \mu \mathrm{m}$ reported by Duchêne (1980) for the terebellid, Neoleprea streptochaeta. Fecundity in $R$. callforniensis, 44 , is very small. Nicolea zostericola, which is approximately the same size as $R$. californiensis but produces eggs of $300 \mu \mathrm{m}$, has a maximum fecundity of 665 for its single, discrete spawning period (Eckelbarger, 1974). Nonetheless, the number of larvae produced by these two species in a lifetime may be comparable, because $R$. californiensis can have up to $11 \mathrm{co-}$ coons at any one time, and apparently lays additional cocoons over time. The fecundity of T. crispus, 51,555, is very high compared to other large intratubular brooding polychaetes, like some sabellids (G. Rouse, pers. comm.). It is much smaller than the fecundity of large free-spawning species in the study, $N$. robusta, but the reproductive output of $T$. crispus is closer to the two free-spawning species in the study than to $R$. californiensis (see Table II). Pairing of males and females prior to reproduction, as has been described in N. zostericola (Eckelbarger, 1974), has not been observed in either $R$. californiensis or $T$. crispus. However, some special mode of sperm transfer seems necessary in these two species to accommodate fertilization of eggs before cocoon or egg mass formation within the tube. In $R$. californiensis, this speculation is supported by the presence of elongated sperm $(\sim 10 \mu \mathrm{m}$ : pers. obs.).

Despite their similar egg sizes, $R$. californiensis and $T$. crispus differ substantially in their dispersal potentials. Ramex californiensis undergoes direct development with no planktonic stage, whereas $T$. crispus has a mixed mode of development with brooded larvae that undergo a short- 
lived planktonic stage. Development in $R$. californiensis most closely resembles that of $N$. streptochaeta, in which juveniles of 10 setigers emerge from the maternal tube after a lengthy period of intratubular development (Duchêne, 1980). The 11-setiger juveniles of $R$. californiensis can build mucus tubes and feed on detrital matter; they avoid whatever mortality risks of planktonic development there might be. The rate of post-settlement mortality in either species is unknown, however, in $R$. californiensis at least, it is unlikely that there are any negative intraspecific interactions between adults and juveniles as seen in E. nebulosa (Bhaud, 1990, 1991), because of the small adult size in this species and the tubicolous habit of newly emerged juveniles.

The mixed development of $T$. crispus is similar to that of T. setosus and E. nebulosa (Bhaud and Grémare, 1988; Duchêne, 1991). In both species of Thelepus, the planktonic period of development is short ( $\sim 1$ day), and $T$. crispus larvae, at least, are poor swimmers. This may restrict the dispersal of the larvae, effectively isolating different populations of the species. The population genetics of $T$. crispus, $R$. californiensis, and E. crescentis, species with larval planktonic periods ranging from 0 to 7 days, are being investigated to reveal whether the degree of genetic exchange among populations of each species corresponds with their differing dispersal potentials.

\section{Comparative data}

Correlation analyses of the matrix of reproductive and developmental traits for the 11 species in the study reveal several expected trends, but also a few that are contrary to widely accepted generalizations regarding the covariation of life history traits. Fgg size is an important life history trait; it is an indicator of maternal investment per offspring, is easily measured, and is correlated with several other life history traits in marine invertebrates. Thorson (1950) reported that egg size is correlated with fecundity and development mode in several marine invertebrate groups, and these trends have also been noted for polychaetes in general (Schroeder and Hermans, 1975), and some polychaete families in particular (e.g., Sabellidae: McEuen et al., 1983). Egg volume ranges over two orders of magnitude among the Terebellidae, and the relationship between egg size and mode of reproduction has been noted for several terebellid species in the past (Blake, 1991; Bhaud, 1988). However, this is the first study in which a significant difference in egg size among reproductive modes has been demonstrated for this or any polychaete family. Egg size increases with the degree of parental care provided to the larvae, with intratubular brooders having the largest eggs and free-spawning species the smallest. In echinoderms, egg size is generally correlated with energetic content (Emlet et al., 1987), however, no studies on the energetic content of terebellid eggs have been published. Nonetheless, from the observations of this study it is expected that egg size (i.e., oocyte diameter) is also correlated with energetic content among terebellid species.

It is usually assumed that for organisms of comparable size, smaller eggs are associated with increased fecundity, and vice versa (Olive et al., 1984). While egg size is a commonly reported variable in studies on reproduction and development, data on fecundity in many marine invertebrate groups are not available, and the trade off between these two life history traits has not often been investigated. The present study is the first in which fecundity of different polychaete species is compared with other reproductive traits. Initial correlation analysis indicates that the trade off between egg size and fecundity is as expected among terebellids; however, multiple regression analysis shows that egg size does not predict fecundity if body size is held constant. In a regression analysis of life history traits in oysters, Buroker (1985) found no significant relationship between egg size and fecundity. These results demonstrate that generalizations regarding the relationship between these two traits are not appropriate until further comparative investigations in other groups are made; the relationship is obviously complex, and may be linked to reproductive effort or larval survivorship, neither of which are well known for polychaetes.

All terebellids in the study undergo external fertilization, i.e., copulation is absent, and there is no evidence of self fertilization in any terebellid species, although rarely hermaphrodites have been observed (e.g., Ramex californiensis, pers. obs.; Pista pacifica, R. I. Smith, pers. comm.). In Nicolea zostericola, which broods its embryos in an extratubular cocoon, males and females pair before spawning and sperm is gathered in the short oral tentacles of the female before mature eggs are passed over the tentacles for fertilization (Eckelbarger, 1974). This is the case also in the intratubular brooder, Neoleprea streptochaeta (Duchêne, 1980), but not Eupolymnia nebulosa, in which eggs in an extratubular gelatinous mass are fertilized by free sperm in the water (Smith, 1989a). Unfortunately, sperm ultrastructure, which is generally indicative of fertilization mechanism in polychaetes (see Jamieson and Rouse, 1989), has been reported for only one terebellid species, $N$. zostericola (Eckelbarger, 1975). Additional studies of this aspect of terebellid reproduction would provide more insights into the fertilization biology of this group.

While terebellids display a great variety of reproductive modes, one feature shared by the species in this comparative study is the use of endogenous nutrient supplies during larval development. Two terebellid species feed in the plankton, but this occurs during a secondary planktonic stage after metamorphosis (aulophore stage) (Wilson, 1928; Heimler, 1981; Bhaud, 1988). Newly metamor- 
phosed juveniles of Lanice conchilega and Loimia medusa engage in this activity, which is functionally equivalent to larval feeding, i.e., it involves ingestion of plankton and potential increased dispersal during the planktonic feeding period, but morphologically it is a very different process; larval cilia are not used in feeding or in locomotion during the planktonic stage (Heimler, 1981; Bhaud, 1988). Therefore, the planktonic stage must be considered analogous rather than homologous to planktotrophic larva (Bhaud, 1988).

In marine invertebrates generally, planktotrophic larval development has been proposed as the common ancestral condition (Jägersten, 1972; Strathmann, 1978). The evolutionary loss of larval feeding involves the loss of ciliary feeding bands and sometimes the whole larval gut, and the probability of regaining these feeding structures is thought to be so unlikely that a biased transition from planktotrophy to lecithotrophy is expected (Strathmann, 1985). The descendents from a lineage from which larval feeding forms have been lost will be restricted in their options for development modes (Strathmann, 1978, 1985). Once development is constrained, the evolution of other life history traits like egg size and fecundity may also be affected. The present study emphasizes the absence of larval feeding in terebellids, a well-defined polychaete family that is found in all marine habitats. Assuming the monophyly of terebellids, lecithotrophy apparently represents a fixed trait in this group. 'Ihis contrasts with the occurrence of both planktotrophy and lecithotrophy in other polychaete families (e.g., Spionidae, Cirratulidae, Nereidae, Onuphidae, Dorvilleidae, and Serpulidae) (Wilson, 1991), and suggests that development has been constrained during the evolution of the terebellid lineage. Alternatively, lecithotrophy may be selectively advantageous in terebellids; planktotrophy may be an option that has never been favored. This hypothesis seems implausible given the diversity of habitats occupied by members of the family Terehellidae.

No studies on field mortality rates of terebellid larvae have been published, although Bhaud (1991) reported low mortality rates of Eupolymnia nebulosa larvae under lab conditions. Terebellid larvae lack defensive structures seen in some polychaete larvae (Bhaud and Cazaux, 1982; Pennington and Chia, 1984), and they are poor swimmers, in which buoyancy appears to play a major role in the maintenance of a planktonic existence (Nyholm, 1951; pers. obs.). These features of terebellid larvae suggest that they are probably vulnerable to predation in the plankton, with increasing size during development being their only protection. Brooding of larvae is presumably less hazardous than planktonic development, and in terebellids the fertilization efficiency among brooders is thought to be substantially higher than in broadcast spawning species (Eckelbarger, 1974; Duchêne, 1980). Mixed development involves brooding followed by a planktonic larval period (Pechenik, 1979). Initial brooding likely increases fertilization efficiency and provides protection for the early stages. The maintenance of a planktonic stage, despite the possible increased mortality risks, suggests some selective advantage associated with dispersal or some disadvantage associated with no dispersal; alternatively, functional limits (e.g., space, oxygen requirements) may prohibit brooding of larvae beyond certain stages. In any case, the significantly higher fecundities among terebellids with mixed development compared with those with direct development may compensate for any increased mortality risks associated with planktonic stages.

Juvenile stage (number of setigers), which differs significantly among reproductive modes, is significantly correlated with egg size in terebellids. As larval development in terebellids is apparently dependent on yolk supplies, this relationship between egg size and juvenile stage is not surprising; in the absence of planktonic feeding, larger eggs will give rise to larger, more developed juveniles (Strathmann, 1985). Interestingly, there is no correlation between the number of days during development spent in the plankton and the initial egg size. This is also the case in some cirripedes (Barnes and Barnes, 1965), and it follows the prediction of Strathmann (1977) that the larval period will be independent of egg size, if size at metamorphosis increases with increasing egg size.

If, as previously mentioned, brooding of larvae is the safest mode of development, then all other things being equal, all marine invertebrates would brood their larvae (Emlet et al., 1987). However, among related species, if any of them brood it is usually only the smaller ones (Strathmann and Strathmann, 1982; Strathmann et al., 1984). Numerous studies have confirmed this association of brooding with small body size in a wide variety of groups, including echinoderms (e.g., Menge, 1975), mollusks (Pearse, 1979; Sastry, 1979), and some polychaetes (Knight-Jones and Bowden, 1984). Various hypotheses have been invoked to explain this pattern, and the one based on allometric constraints has been supported by several studies (Strathmann and Chaffee, 1984; Strathmann et al., 1984; McClary and Mladenov, 1989). In organisms of increasing size, fecundity increases disproportionately with the surface area available for brooding, therefore larger animals are less capable of retaining and ventilating all the offspring that they can produce; small animals are less likely to encounter this problem (Strathmann and Strathmann, 1982). Terebellids, however, do not support this hypothesis. Indeed, the terebellids in the present study provide a clear exception to the generalization that large body size may be incompatible with brooding in marine invertebrates. One of the largest species in the study, Thelepus crispus, broods its embryos in its tube, as does one of the smallest species in the study, Ramex 
californiensis. While reproductive output is expected to be limited by space in large, tubicolous polychaetes (Hines, 1986), there does not appear to be a substantial limitation in terebellids when large broadcast spawners are compared with a large intratubular brooder in the present study (see Table II). It is possible that large terebellids, and perhaps other sedentary polychaetes, can overcome the suggested constraints of brooding by (i) having a tube that has greater surface area than the body (i.e., longer, wider), or (ii) by ventilating the tube well with peristalitic contractions of the body, as has been described by Dales (1961) for several terebellid species. In some other marine invertebrates, scaling constraints do not provide adequate explanation for the association of brooding with small size; Hess (1993) found no evidence of allometric contraints on brood size in spirorbid polychaetes (1-3 mm in length), and Kabat (1985) showed that brood area does not constrain reproductive output in the small bivalve, Transenella tantilla (6 $\mathrm{mm}$ shell length).

From the matrix of reproductive and developmental traits, it is clear that brooders show wider ranges of values for all traits than broadcasting species (Table V). This probably reflects the grouping of species with functionally similar reproductive modes that are of different evolutionary origins. Only with a phylogenetic analysis of the family will it be possible to address such issues. With such an analysis we can also begin to evaluate how much of the variation in life history traits is due to phylogenetic effects, and how much is the result of adaptation to different selective environments, as has already been done for some vertebrate groups (e.g., Harvey and CluttonBrock, 1985; Gittleman, 1986; Miles and Dunham, 1992). Although biases in the data are likely, due to the nonrandom way in which subjects were chosen, and the phylogenetic effects on life history traits can only be speculated upon for now, the results of this study nonetheless show that generalizations about the covariation of life history traits in marine invertebrates need to be viewed with caution. The exceptions to some commonly held assumptions provided by the Terebellidae show that more comparative studies of marine invertebrate reproduction and development are needed to broaden our base for life history theories.

\section{Acknowledgments}

This paper is dedicated to the memory of Dr. Ralph I. Smith, who introduced me to the terebellids of the central California coast. I am grateful to him, and also to Dr. John S. Pearse for their support, advice, and encouragement throughout this study. I thank them, Drs. G. W. Rouse and P. D. Reynolds, and two anonymous reviewers for critical reviews of the manuscript. Dr. G. Griggs, Director, Long Marine Laboratory and Institute of Marine
Sciences, University of California, Santa Cruz; Dr. J. Clegg, Director, Bodega Marine Laboratory; and Dr. A. O. D. Willows, Director, Friday Harbor Laboratories, graciously provided the use of those facilities. I thank $J$. Kurpius for assistance with oocyte measurements, B. Steele for help with larval culture and maintenance, G. Pierce for advice on statistics, and S. Edmands, P. Fong, J. Kurpius, E. McHugh, C. E. Mills, P. D. Reynolds, R. I. Smith, and P. Wolfe for accompanying me on field trips. Some collection of data and revisions of the manuscript were made while the author was a Scholar-in-Residence at Hamilton College. Financial support from the following sources is gratefully acknowledged; Biology Independent Study Funds, University of California, Santa Cruz; the Society for Sigma Xi; the Dr. E. H. and E. M. Myers Oceanographic and Marine Biology Trust; the Friends of Long Marine Laboratory; and the Lerner-Gray Fund for Marine Research (American Museum of Natural History).

\section{Literature Cited}

Barnes, H., and M. Barnes. 1965. Egg size, nauplius size, and their variation with local, geographical, and specific factors in some common cirripedes. J. Anim. Ecol. 34: 391-402.

Bhaud, M. 1988. The two planktonic larval periods of Lanice conchilega (Pallas, 1766) Annelida Polychaeta, a peculiar example of the irreversibility of evolution. Ophelia 29(2): 141-152.

Bhaud, M. 1990. Conditions d'éstablissement des larves de Eupolymnia nebulosa: acquis expérimentaux et observations en milieu natural; utilité d'une confrontation. Océanis 16(3): 181-189.

Bhaud, M. R. 1991. Larval release from the egg mass and settlement of Eupolymnia nebulosa (Polychaeta, Terebellidae). Bull. Mar. Sci. 48(2): 420-431.

Bhaud, M., and C. Cazaux. 1982. Les larves de polychêtes des cotes de France. Océanis 8: 57-160.

Bhaud, M., and A. Grémare. 1988. Larval development of the terebellid polychaete Eupolymnia nebulosa (Montagu) in the Mediterranean Sea. Zool. Scripta 17(4): 347-356.

Bhaud, M., A. Grémare, F. Lang, and C. Retiére. 1987. Ẽtude comparées des caractères reproductifs du terebellien Eupolymnia nebulosa (Montagu) (Annélide Polychète) en deux points de son aire géographique. C. R. Acad. Sci. Paris Série III 304(5): 119-122.

Blake, J. A. 1991. Larval development of Polychaeta from the northern California coast V. Ramex californiensis Hartman (Polychaeta: Terebellidae). Bull. Mar. Sci. 48(2): 448-460.

Buroker, N. E. 1985. Evolutionary patterns in the family Ostreidae: larviparity vs. oviparity. J. Exp. Mar. Biol. Ecol. 90: 233-247.

Chia, F-S. 1974. Classification and adaptive significance of developmental patterns in marine invertebrates. Thallassia Jugoslav. 10: 121120.

Christiansen, F. B., and T. M. Fenchel. 1979. Evolution of marine invertebrate reproductive patterns. Theor. Pop. Biol. 16: 267-282.

Dales, R. P. 1961. Oxygen uptake and irrigation of the burrow by three polychaetes: Eupolymnia, Thelepus and Neoamphitrite. Physiol. Zool. 34: 306-311.

Day, J. H. 1967. A Monograph on the Polychaeta of Southern Africa. British Museum of Natural History Publications, London.

Doyle, R. W., and W. Hunte. 1981. Genetic changes in "fitness" and yield of a crustacean population in a controlled environment. $J$. Exp. Mar. Bio. Ecol. 52: 147-156. 
Duchêne, J. C. 1979. Premières données sur la reproduction et la croissance de la polychète Thelepus setosus (Terebellidae) en province subantarctique. Ann. Inst. Océanogr. Paris 55(2): 145-154.

Duchêne, J. C. 1980. Premières données sur la reproduction at la croissance de la polychète Neoleprea streptochaeta (Terebellidae) en province subantarctique. Ann. Inst. Océanogr. Paris 56(2): 109-115.

Duchêne, J. C. 1991. Growth rate, fecundity and spawning in two subantarctic populations of Thelepus setosus (Quatrefages) (Polychaeta: Terebellidae). Ophelia Suppl. 5: 313-320.

Dunham, A. E., and D. B. Miles. 1985. Patterns of covariation in life history traits of squamate reptiles: the effect of size and phylogeny reconsidered. Am. Nat. 126: 231-257.

Eckelbarger, K. J. 1974. Population biology and larval development of the terebellid polychaete Nicolea zostericola. Mar. Biol. 27: 101113.

Eckelbarger, K. J. 1975. A light and electron microscope investigation of gametogenesis in Nicolea zostericola (Polychaeta: Terebellidae). Mar. Biol. 30: 353-370.

Eckelbarger, K. J. 1976. Origin and development of the amoebocytes of Nicolea zostericola (Polychaeta: Terebellidae) with a discussion of their possibie role in oogenesis. Mar. Biol. 36: 169-182.

Emlet, R. B., L. R. McEdward, and R. R. Strathmann. 1987. Echinoderm larval ecology viewed from the egg. Echinoderm Studies 2: 55-136.

Fauchald, K. 1983. Life diagram patterns in benthic polychaetes. Proc. Biol. Soc. Wash. 96(1): 160-177.

Gittleman, J. L. 1986. Carnivore life history patterns: allometric, phylogenetic, and ecological associations. Am. Nat. 127: 744-771.

Grant, A. 1990. Mode of development and reproductive effort in marine invertebrates: should there be any relationship? Func. Ecol. 4(1): 128129.

Grémare, A. 1986. A comparative study of reproductive energetics in two populations of the terebellid polychaete Eupolymnia nebulosa Montagu with different reproductive modes. J. Exp. Mar. Biol. Ecol. 96: 287-302.

Grémare, A., and P. J. W. Olive. 1986. A preliminary study of fecundity and reproductive effort in two polychaetous annelids with contrasting reproductive strategies. Int. J. Invert. Repro. Dev. 9: 1-16.

Hannan, C. A., L. W. Hulberg, K. M. Mawn, and J. W. Nybakken. 1977. A Study to Develop Standard Procedures for Life History Analyses of Benthic Invertebrates for Biological Monitoring in Marine and Estuarine Environments. Moss Landing Marine Laboratories, California State University Consortium. 217 pp.

Hart, M. W. 1992. Larval feeding performance and egg size evolution in echinoids. Am. Zool 32(5): 114A.

Hartman, O. 1969. Atlas of Sedentariate Polychaetous Annelids from California. Allan Hancock Foundation, University of Southern California, Los Angeles. 812 pp.

Harvey, P. H., and T. H. Clutton-Brock. 1985. Life history variation in primates. Evolution 39(3): 559-581.

Heimler, W. 1981. Untersuchungen zur Larvalentwicklung von Lanice conchilega (Pallas) 1766 (Polychaeta, Terebellomorpha) Teil I: Entwicklungsablauf. Zool. Jb. Anat. 106: 12-45.

Hess, H. C. 1993. The evolution of parental care in brooding spirorbid polychaetes: the effect of scaling constraints. Am. Nat. 141: 577-596.

Hines, A. H. 1982. Allometric constraints and variables of reproductive effort in brachyuran crabs. Mar. Biol. 69: 309-320.

Hines, A. H. 1986. Larval problems and perspectives in life histories of marine invertebrates. Bull. Mar. Sci. 39(2): 506-525.

Jägersten, G. 1972. Evolution of the Metazoan Iife Cycle Academic Press, London and New York.

Jamieson, B. G. M., and G. W. Rouse. 1989. The spermatozoa of the Polychaeta (Annelida): an ultrastructural review. Biol. Rev. 64: 93157.
Kabat, A. R. 1985. The allometry of brooding in Transenella tantilla (Gould) (Mollusca: Bivalvia). J. Exp. Mar. Biol. Ecol. 91: 271-279.

Knight-Jones, P., and N. Bowden. 1984. Incubation and scissiparity in Sabellidae (Polychaeta). J. Mar. Biol. Assoc. U.K. 64: 809-818.

Marinescu, V.P. 1964. I a reproduction et le dévelooppement des polychètes reliques ponto-caspiens du Danube: Hypaniola kowalewskii (Grimm) et Manayunkia caspica. Ann. Rev. Roum. Biol. (série Zool.) 9: $87-100$.

McClary, D. J., and P. V. Mladenov. 1989. Reproductive pattern in the brooding and broadcasting sea star Pteraster militaris. Mar. Biol. 103: $531-540$.

McEdward, L. R., and F.-S. Chia. 1991. Size and energy content of eggs from echinoderms with pelagic lecithotrophic development. $J$. Exp. Mar. Biol. Ecol. 147: 95-102.

McEuen, F. S., B. L. Wu, and F.-S. Chia. 1983. Reproduction and development of Sabella media, a sabellid polychaete with extratubular brooding. Mar. Biol. 76: 301-309.

Mead, A. D. 1897. The early development of marine annelids. J. Morphol. 3(2): 227-326.

Menge, B. 1975. Brood or broadcast? The adaptive significance of different reproductive strategies in the two intertidal sea-stars Leptasterias hexactis and Pisaster ochraceus. Mar. Biol. 31: 87-100.

Miles, D. B., and A. E. Dunham. 1992. Comparative analyses of phylogenetic effects in the life-history patterns of iguanid reptiles. $\mathrm{Am}$. Nat. 139(4): 848-869.

Nyholm, K.-G. 1951. Contributions to the life-history of the ampharetid, Melinna cristata. Zool. Bidr. Uppsala 29: 79-93.

Olive, P. J. W. 1984. Environmental control of reproduction in Polychaeta. Fortschr. Zool. 29: 17-38.

Olive, P. J. W. 1985. Covariability of reproductive traits in marine invertebrates: implications for the phylogeny of the lower invertebrates. Pp. 42-59 in The Origin and Relationships of Lower Inverlebrates, Conway Morris, S., D. George, R. Gibson, and H. M. Platt, eds. Oxford University Press.

Olive, P. J. W., P. J. Morgan, N. H. Wright, and S. L. Zhang. 1984. Variable reproductive output in Polychaeta; options and design constraints. Pp. 399-408 in Advances in Invertebrate Reproduction, Vol. 3, W. Engels, ed. Elsevier Science Publications, New York.

Pearse, J. S. 1979. Polyplacophora. Pp. 27-86 in Reproduction of Marine Invertebrates, Vol. 5, A. C. Giese and J. S. Pearse, eds. Academic Press, New York.

Pechenik, J. A. 1979. Role of encapsulation in invertebrate life histories. Am. Nal. 114: 859-870.

Pennington, J. T., and F-S. Chia. 1984. Morphological and behavioral defenses of trochophore larvae of Sabellaria cementarium (Polychaeta) against four planktonic predators. Biol. Bull. 167: 168-175.

Roughgarden, J. 1989. The evolution of marine life cycles. Pp. 270300 in Mathematical Evolutionary Theory, M. Feldman, ed. Princeton University Press, Princeton, New Jersey.

Saether, B.-E. 1988. Pattern of covariation between life-history traits of European birds. Nature 331: 616-617.

Sastry, A. N. 1979. Pelecypoda (excluding Ostreidae). Pp. 113-292 in Reproduction of Marine Invertebrates, Vol. 5, A. C. Giese and J. S. Pearse, eds. Academic Press, New York.

Schroeder, P. C., and C. O. Hermans. 1975. Annelida: Polychaeta. Pp. 1-214 in Reproduction of Marine Invertebrates, Vol. 3, A. C. Giese and J. S. Pearse, eds. Academic Press, New York.

Scott, J. W. 1909. Some egg-laying habits of Amphitrite ornata Verrill. Biol. Bull. 17: 327-340.

Scott, J. W. 1910. Further experiments on the methods of egg-laying in Amphitrite. Biol. Bull. 20: 252-265.

Sinervo, B. R., and L. R. McEdward. 1988. Developmental consequences of an evolutionary change in egg size: an experimental test. Evolution 42(5): 885-899. 
Smith, R. I. 1989a. Observations on spawning behavior of Eupolymnia nebulosa, and comparisons with Lanice conchilega (Annelida, Polychaeta, Terebellidae). Bull. Mar. Sci. 45(2): 406-414.

Smith, R. I. 1989b. Notes on gamete production in Lanice conchilega (Annelida, Polychaeta, Terebellidae). Invert. Rep. Dev. 15: 7-12.

Sokal, R. R., and F. J. Rohlf. 1981. Biometry. Freeman, New York. $324 \mathrm{pp}$.

Spight, T. M., C. Birkeland, and A. Lyons. 1974. Life histories of large and small murexes (Prosobranchia: Muricidae). Mar. Biol. 24: 229242.

Stearns, S. C. 1983 . The influence of size and phylogeny on patterns of covariation among life-history traits in mammals. Oikos 41: 173 187.

Stearns, S. C. 1984a. The effects of size and plylogeny on patterns of covariation in the life history traits of lizards and snakes. Am. Nat. 123: $56-72$.

Stearns, S. C. 1984b. The tension between adaptation and constraint in the evolution of reproductive patterns. Pp. 387-398 in Advances in Invertebrate Reproduction, Vol. 3. W. Engels, ed. Elsevier Science Publishers, New York.

Strathmann, M. F. 1987. Reproduction and Development of Marine Invertebrates of the Northern Pacific Coast. Data and Methods for the Study of Eggs, Embryos, and Larvae. University of Washington Press, Seattle and London. $670 \mathrm{pp}$

Strathmann, R. R. 1977. Egg size, larval development, and juvenile size in benthic marine invertebrates. Am. Nat. 108: 29-44.

Strathmann, R. R. 1978. The evolution and loss of feeding larval stages of marine invertebrates. Evolution 32: 894-906.
Strathmann, R. R. 1985. Feeding and nonfeeding larval development and life-history evolution in marine invertebrates. Ann. Rev. Ecol. Syst. 16: 339-361.

Strathmann, R. R. 1986. What controls the type of larval development? Summary statement for the evolution session. Bull. Mar. Sci. 39(2): 616-622.

Strathmann, R. R., and C. Chaffee. 1984. Constraints of egg masses. II. Effect of spacing, size, and number of eggs on ventilation of masses of embryos in jelly, adherent groups, or thin-walled capsules. J. Exp. Mar. Biol. Ecol. 84: 85-93.

Strathmann, R. R., and M. F. Strathmann. 1982. The relation between adult size and brooding in marine invertebrates. Am. Nat. 119: 91101.

Strathmann, R. R., M. F. Strathmann, and R. H. Emson. 1984. Does limited brood capacity link adult size, brooding and simultaneous hermaphroditism? A test with the starfish Asterina phylactica. Am. Nat. 123(6): 796-818.

Thorson, G. 1950. Reproduction and larval development of marine benthic invertebrates. Biol. Rev. 25: 1-45.

Trendall, J. T. 1982. Covariation of life history traits in the mosquitofish, Gambusia affinis. Am. Nat. 119(6): 774-783.

Vance, R. R. 1973. On reproductive strategies in marine benthic invertebrates. Am. Nat. 107: 339-352.

Wilson, D. P. 1928. The post-larval development of Loimia medusa Sav. J. Mar. Biol. Assoc. U.K. 15: 129-149.

Wilson, W. H. 1991. Sexual reproductive modes in polychaetes: classification and diversity. Bull. Mar. Sci. 48(2): 500-516. 